New Books

THE EARLY CHURCH

Historical and Theological Studies

Oscar Cullmann, edited by A. J. B. Higgins 25s net

STUDIES IN THE ACTS OF THE APOSTLES

Martin Dibelius, translated by Mary Ling 25s net

Two new Studies in Biblical Theology

GALILEAN CHRISTIANITY

L. E. Elliott-Binns, Canon Emeritus of Truro

Cathedral

$7 s 6 d$ net

CONSCIENCE IN THE NEW TESTAMENT

C. A. Pierce, Chaplain of Magdalene College,

Cambridge

9s $6 d$ net

SCM PRESS

\section{The Indian}

Christians of

\section{St Thomas}

\section{W. BROWN}

The Christians in Malabar claim an unbroken religious tradition from the time of Thomas the Apostle, who is said to have visited India. This study tells their history and explains the special forms of their religious observances.

40s. net

CAMBRIDGE UNIVERSITY PRESS
TYNDALE COMMENTARIES

Old Testament Editor

Professor E. J. Y OUNG

New Testament Editor

Professor R. V. G. TASKER

This series of inexpensive commentaries on books in both the Old and New Testaments is planned for the non-specialist Bible student. The first two titles will be published this Autumn, as follows:

\section{THE EPISTLE OF JAMES}

By the Rev. R. V. G. TASKER, M.A., B.D. I44 Pp. $75.6 \mathrm{~d}$.

I AND II THESSALONIANS By LeON MORris, B.SC., M.TH., PH.D. I52 pp. $7 s .6 d$.

Other contributors to the series will include Professor F. F. Bruce, Professor N. B. Stonehouse, the Rev. A. M. Stibbs, Mr Donald Wiseman and the Rev. T. Hewitt.

THE TYNDALE PRESS 39 Bedford Square, London, W.C. I 


\section{St Peter \\ BY JOHN LOWE}

Because a just appreciation of the subject has often been hindered by the controversies connected with the Papal claims, the Dean of Christ Church, Oxford, has here attempted to put together afresh in brief compass the facts and probabilities about St Peter in the light of the earliest evidence, including that of the recent Vatican excavations.

80 pages

Ios. $6 d$. net

\section{Principalities and Powers \\ A Study in Pauline Theology \\ BY G. B. CAIRD}

This study has been undertaken on the assumption that when St Paul speaks of principalities, powers, world-rulers, and elemental spirits, he is using mythological language to describe spiritual realities known to him. Professor Caird traces the Jewish beliefs that contributed to Paul's theology in this respect and shows how Paul understood the Cross as a victory over these powers.

120 pages

15s. net

\section{The Idea of Revelation in Recent Thought}

\section{BY JOHN BAILLIE}

What we mean by revelation is a question, says Dr Baillie, 'to which much hard thought and careful writing are being devoted in our time'. The traditional clear-cut distinction between truths of reason and truths of revelation has broken down and it is questioned whether revelation can be conceived as a set of divinely-given propositions. By reviewing recent thought on the subject Dr Baillie himself makes a valuable contribution to the discussion.

176 pages

I5s. net

\section{Now published \\ The Suffering Servant in Deutero-Isaiah An Historical and Critical Study \\ BY C. R. NORTH}

Second edition

25s. net

OXFORD UNIVERSITY PRESS 